\title{
Variability of sea-ice conditions in the Fram Strait over the past 30,000 years
}

\author{
Juliane Müller ${ }^{1 \star}$, Guillaume Massé ${ }^{2,3}$, Rüdiger Stein ${ }^{1}$ and Simon T. Belt ${ }^{3}$
}

\begin{abstract}
Sea ice is a critical component of the climate system: variations in sea-ice cover affect the albedo of polar regions, and also the rate of deepwater formation ${ }^{1,2}$. Changes in the sea-ice cover of the North Atlantic Ocean are thought to have been related to abrupt climate changes throughout the last glacial termination ${ }^{3}$, but reconstructions of sea-ice conditions are rare. Here we use the sedimentary abundance of the $\mathbf{I P}_{25}$ and brassicasterol biomarkers, produced by sea-ice-associated diatoms and open-water phytoplankton, respectively, to generate a record of sea-ice conditions in the northernmost Atlantic Ocean for the past 30,000 years. Our reconstruction shows that a stationary margin between sea-ice cover and the open ocean existed during the Last Glacial, although perennial sea-ice cover prevailed for most of the Last Glacial Maximum. An early warming about 14,000 years ago was associated with ice-free conditions; however, seasonal sea ice was present throughout the Holocene. We find temporal links between our record of sea ice and reconstructions of the amount of relatively warm Atlantic water advected into the Nordic Seas ${ }^{4,5}$. We therefore conclude that changes in sea-ice conditions are linked to regional and global climate anomalies and oceanographic circulation in the North Atlantic.
\end{abstract}

The distribution of sea ice in Fram Strait, the only deepwater connection $(\sim 2,600 \mathrm{~m}$ mean water depth) between the Arctic and Atlantic oceans, is mainly controlled by the inflow of temperate water from the North Atlantic along the western continental margin of Spitsbergen through the Norwegian and West Spitsbergen currents ${ }^{1}$. In contrast, the East Greenland current carries cold water (and sea ice) southward through this gateway ${ }^{1}$ (Fig. 1). The relative contributions of these currents strongly influence the thermohaline circulation, thus contributing to global climate ${ }^{1}$.

Previously, it has been shown that, when detected in marine sediments, a $\mathrm{C}_{25}$ isoprenoid lipid $\left(\mathrm{IP}_{25}\right)$ biosynthesized by Arctic sea-ice diatoms acts as a proxy for previous spring sea-ice occurrence and subsequent melt ${ }^{6,7}$, whereas the phytoplanktonderived sterol brassicasterol, reflects open-ocean conditions during summer $^{8}$. In the current study, we present organic carbon ${ }^{9}$ (global productivity and terrigenous organic carbon input) and fluxes of $\mathrm{IP}_{25}$ (sea ice) and brassicasterol (phytoplankton; ref. 9) for a sediment core (PS2837-5) from the western flank of the Yermak Plateau $\left(81^{\circ} 13.99^{\prime} \mathrm{N}, 02^{\circ} 22.85^{\prime} \mathrm{E}\right.$, northwest of Spitsbergen, $1,042 \mathrm{~m}$ water depth; ref. 10) close to the present-day summer sea-ice margin in Fram Strait (Fig. 1). We use the previously reported age model of PS2837-5, which is based on 14 accelerator mass spectrometry ${ }^{14} \mathrm{C}$ ages of tests of the planktic foraminifer Neogloboquadrina pachyderma sin. and assumes a marine-reservoir correction of 400 years and linear interpolation between ${ }^{14} \mathrm{C}$-dated horizons ${ }^{11}$. In the following, ages are given in calibrated calendar years before present.

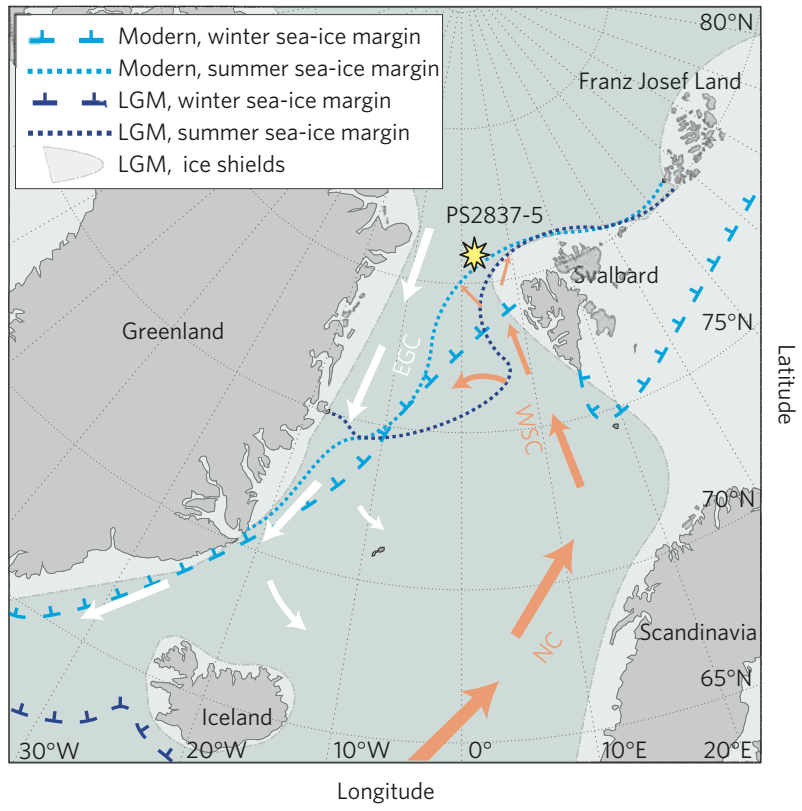

Figure 1 | Map showing the PS2837-5 core site in northern Fram Strait, major ocean currents and sea-ice margins ${ }^{\mathbf{1 4}}$. White-shaded areas indicate the extent of the Greenland, Iceland and Scandinavian Ice Shields during the Last Glacial Maximum. Orange arrows refer to warm Atlantic water inflow through the Norwegian (NC) and West Spitsbergen (WSC) currents; white arrows indicate cold polar water transported by the East Greenland current (EGC; ref. 1).

For much of the interval between 30 and $17 \mathrm{kyr}$ в (Late Weichselian to early deglaciation; Fig. 2), $\mathrm{IP}_{25}$, brassicasterol and organic carbon fluxes are amongst their lowest within the entire record. These near-zero fluxes for all three proxy records, especially during the Last Glacial Maximum (LGM) and the early deglaciation (23.5-17 kyr вр), are attributable to an almost permanent period of ice cover (Fig. 3a), possibly resulting from an extension of the Svalbard-Barents Sea ice sheet (SBIS) to the shelf edge during this time $^{12}$ and a distinct weakening of warm Atlantic water inflow into northern Fram Strait. Under such conditions, diatom and phytoplankton growth is limited because the presence of a thick ice sheet inhibits light penetration and enhanced stratification reduces nutrient availability. These observations demonstrate that the summer sea-ice margin during the LGM must have been located south of about $81^{\circ} \mathrm{N}$ (Fig. 1; refs 13, 14). Exceptionally, elevated $\mathrm{IP}_{25}$ fluxes at about $29.6 \mathrm{kyr}$ вP (Fig. 2) probably indicate a shortterm thinning of this near-perennial sea-ice cover allowing some sea-ice algal growth with subsequent release during a brief summer

\footnotetext{
${ }^{1}$ Alfred Wegener Institute for Polar and Marine Research, 27568 Bremerhaven, Germany, ${ }^{2}$ LOCEAN, UMR7159 CNRS/UPMC/IRD/MNHN, 4 Place Jussieu, 75005 Paris, France, ${ }^{3}$ SEOES, University of Plymouth, Drake Circus, PL48AA Plymouth, UK. *e-mail: juliane.mueller@awi.de.
} 


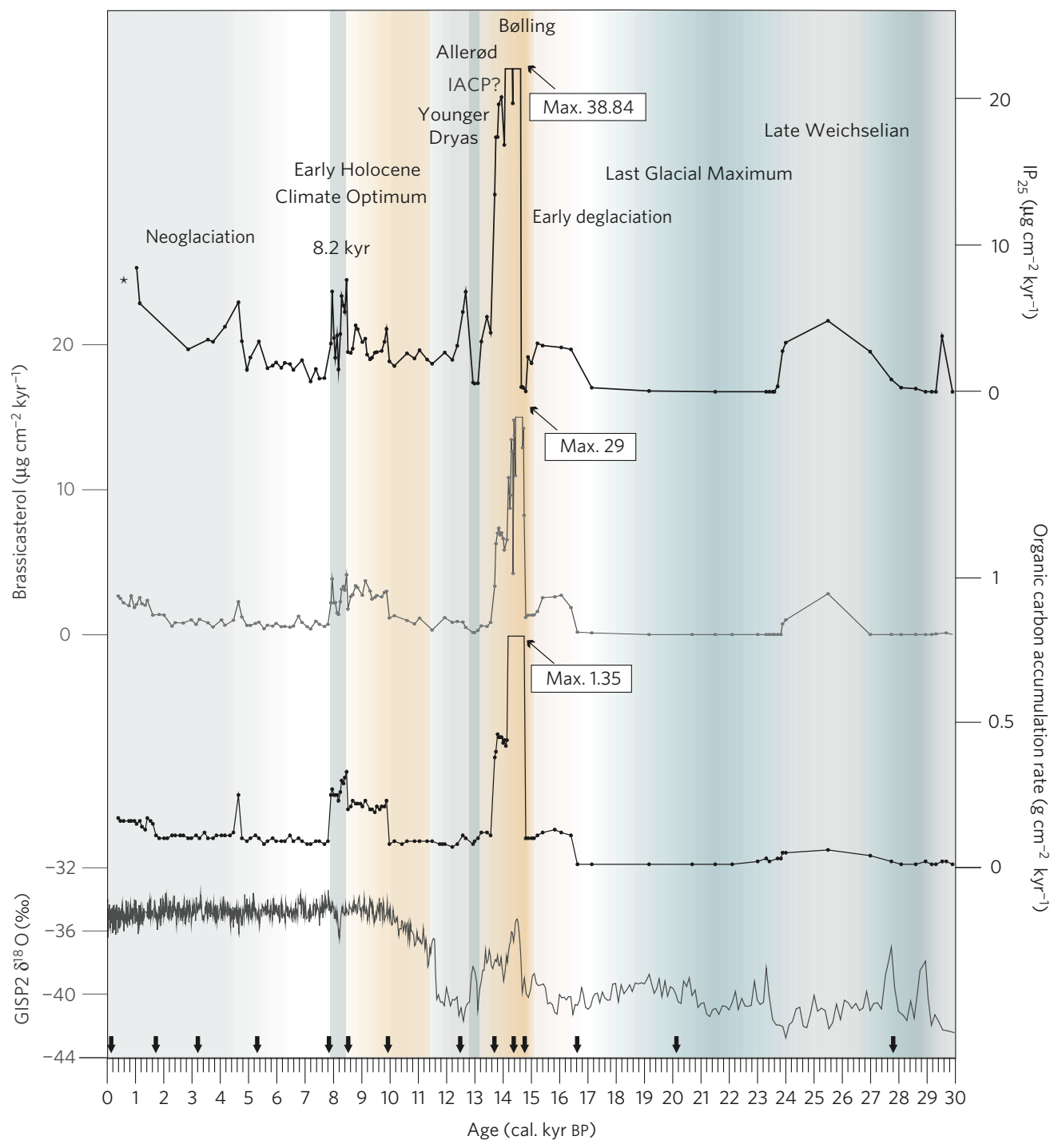

Figure 2 | Temporal evolution of organic carbon ${ }^{9}$, brassicasterol ${ }^{9}$ and IP $_{25}$ accumulation rates (fluxes), and $\delta^{18} 0$ values from the GISP2 ice core ${ }^{22}$. The named geological epochs (for example, Late Weichselian) correspond to intervals for which discrete sea-ice conditions have been identified. Black arrows refer to ${ }^{14} \mathrm{C}$ accelerator mass spectrometry datings. * Interval for which $\mathrm{IP}_{25}$ was not determined.

melt period (Fig. 3a). Between 27 and 24 kyr вр (Fig. 2), increased $\mathrm{IP}_{25}$ and brassicasterol fluxes indicate favourable conditions for both sea-ice diatom and phytoplankton growth. Enhanced marine organic carbon accumulation has also been observed in other cores from Fram Strait and adjacent areas ${ }^{15,16}$ in the vicinity of the SBIS. As primary production is enhanced at the ice edge ${ }^{17}$, resulting in higher sedimentary concentrations of marine-derived biomarkers $^{18}$, these elevated fluxes of $\mathrm{IP}_{25}$ and brassicasterol probably reveal the occurrence of a stationary ice margin (about $81^{\circ} \mathrm{N} ; 2^{\circ} \mathrm{E}$ ) during this otherwise perennially ice-covered interval (Fig. 3b). A coeval enhancement in ice-rafted detritus in PS2837-5 (ref. 11) provides evidence for the presence of drifting sea ice or icebergs at this time and, in turn, the occurrence of coastal polynyas. Such polynyas probably resulted from strengthened Atlantic water advection and/or katabatic winds as suggested previously ${ }^{19}$, with parallel formation of an adjacent stationary ice margin.

Coincident with intensified Atlantic water advection ${ }^{20}$ and the onset of the SBIS disintegration at about $17 \mathrm{kyr}$ вр (refs 12, 16,21 ), higher fluxes of $\mathrm{IP}_{25}$ occurred, probably as a result of reduced ice thickness and thus better light penetration and nutrient availability suitable for sea-ice diatom growth (see $29.6 \mathrm{kyr}$ в event). An increase in brassicasterol and organic carbon fluxes lagged those observed for $\mathrm{IP}_{25}$ by about $400 \mathrm{yr}$ (Fig. 2), consistent with a progressive retreat of the ice sheet and more frequent summer ice melt and open-water conditions. At the onset of the Bølling (about $15 \mathrm{kyr} \mathrm{BP}$ ), a notable abrupt warm phase characterized by heavier GISP2 oxygen isotope $\left(\delta^{18} \mathrm{O}\right)$ values ${ }^{22}$, and exceptionally high sedimentation rates resulting from huge deglacial meltwater plumes carrying high amounts of terrigenous (Svalbard) material ${ }^{9}$, led to extremely high OC and brassicasterol fluxes (Fig. 2). Coeval with this rapid warming, a sudden drop in $\mathrm{IP}_{25}$ fluxes occurred for about $200 \mathrm{yr}(14.8-14.6 \mathrm{kyr}$ вр), reflecting significantly reduced sea-ice occurrence (Fig. 3c). At that time, the Yermak Plateau probably experienced only short-term advances of sea ice, barely sufficient for sea-ice diatoms to populate. On the other hand, open-water phytoplankton would have benefited dramatically from such essentially ice-free conditions.

The Early Bølling was followed by intervals of variable sea-ice cover (about 14.6-13.2 kyr вр), as reflected by the $\mathrm{IP}_{25}$ fluxes. Massive sedimentary input continued during this interval, thus promoting an increased burial-preservation of organic matter (the 'ballast effect'; refs 9, 16) and peak fluxes of organic carbon, brassicasterol and $\mathrm{IP}_{25}$. A prominent short-term decrease in $\delta^{18} \mathrm{O}$ (GISP2), along with reduced $\mathrm{IP}_{25}$, brassicasterol and organic carbon 

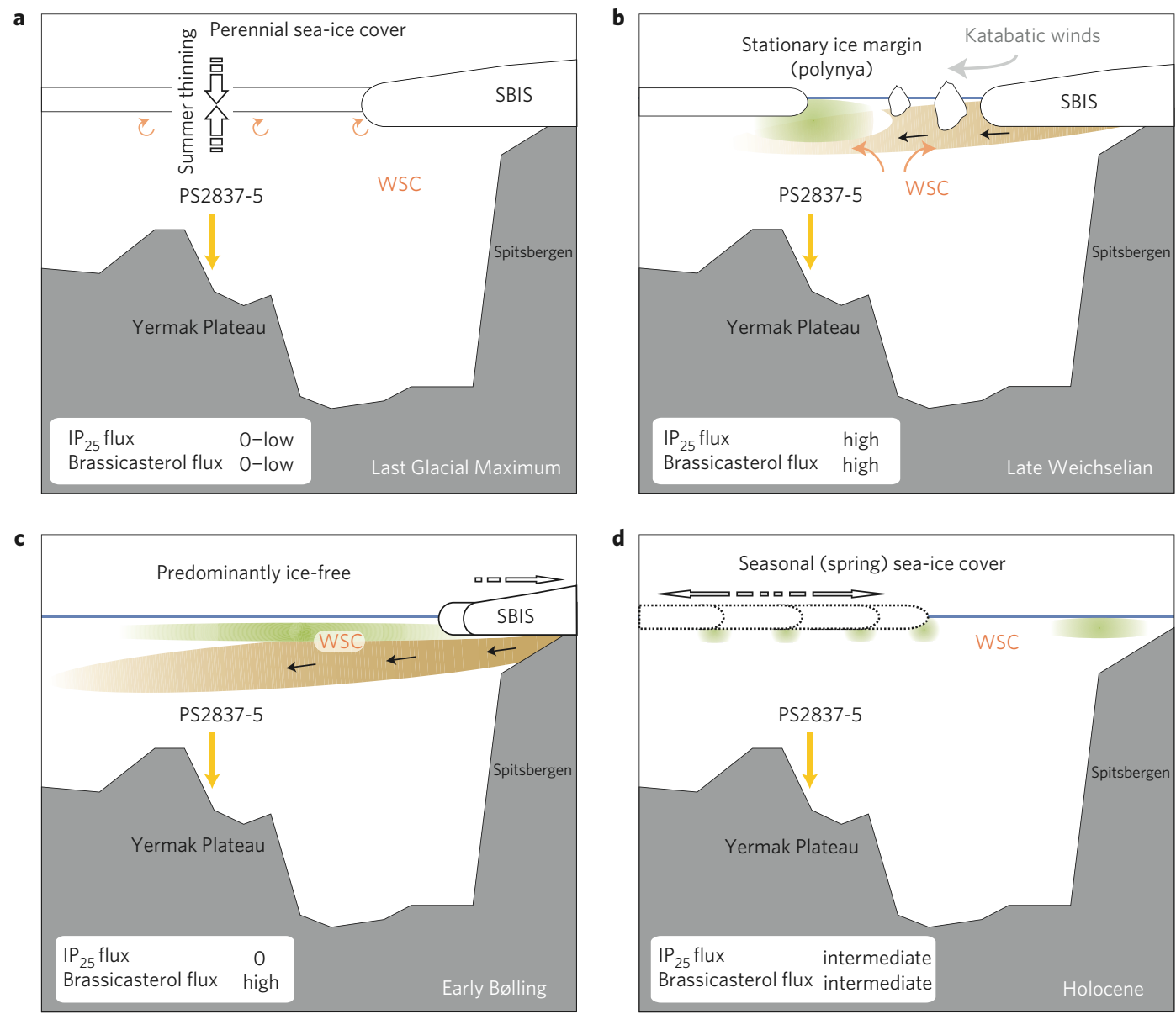

Figure 3 | Schematic illustrations of distinct sea-ice conditions at the PS2837-5 core site for selected time intervals. a-d, Green shadings refer to primary productivity whereas brown shadings indicate input of terrigenous matter. Overview $I P_{25}$ and brassicasterol fluxes are indicated for each interval. WSC $=$ West Spitsbergen current, SBIS = Svalbard-Barents sea-ice sheet.

fluxes, between 13.2 and $13 \mathrm{kyr} \mathrm{BP}$, is consistent with a dramatic temperature decrease over Greenland, and generally unfavourable environmental conditions with extended (perennial) sea-ice cover and reduced primary production (Fig. 3a). These observations, together with an absence of benthic foraminifera in PS2837-5 (ref. 23), are associated with a deterioration of thermohaline processes and reduced bottom-current activity in Fram Strait ${ }^{9}$, and demonstrate that this permanent sea-ice cover affected both primary production and higher trophic levels, resulting in a widespread ecological decline. In previous studies carried out on PS2837-5, this abrupt cooling event was tentatively assigned as the Intra-Allerød Cold Period (IACP; refs 9, 23). However, in the North Atlantic, higher ${ }^{14} \mathrm{C}$ reservoir ages have been determined specifically for this interval (500-600 yr; ref. 24). As these were not considered in the original age model for PS2837-5 (ref. 11), this abrupt cold spell may alternatively be assigned to the Early Younger Dryas (about $12.7 \mathrm{kyr}$ вP), consistent with the common identification of the Younger Dryas as the major cold period in the northern hemisphere following the LGM (refs 25, 26). In further support of this assignment, $\mathrm{IP}_{25}$ and brassicasterol fluxes increased during the subsequent Mid-Late Younger Dryas intervals, as sea-ice diatom and phytoplankton activity improved owing to less severe sea-ice conditions (Fig. 2). Such conditions probably resulted from a weak but constant inflow of warm water from the Atlantic through the West Spitsbergen current, generating climate conditions also suitable for primary productivity, a conclusion consistent with diatom-valve assemblages from the Vøring Plateau in the Norwegian $\mathrm{Sea}^{4}$.
An abrupt increase in GISP2 $\delta^{18} \mathrm{O}$ values, together with numerous terrestrial and marine records, marks the beginning of the Holocene interglacial at around $11.5 \mathrm{kyr}$ вр in northern latitudes ${ }^{22}$. Enhanced insolation and warm Atlantic water influx to the Nordic Seas ${ }^{4,5}$ resulted in a northward retreat of the Polar Front, especially in the Early Holocene, as indicated from foraminiferal and diatom distributions ${ }^{4,27}$. This is further indicated here through the observation of significantly increased brassicasterol and organic carbon fluxes (Fig. 2). However, the co-occurrence of $\mathrm{IP}_{25}$ and the absence of ice-rafted detritus ${ }^{11}$ demonstrates that seasonal sea ice, rather than the presence of polynyas with drifting icebergs and a stationary ice margin, must have prevailed in the northern Fram Strait throughout this period, with changes to the $\mathrm{IP}_{25}$ fluxes reflecting variability of spring sea-ice conditions (Figs 2, 3d). Around $8.4 \mathrm{kyr}$ вр, a short-term increase followed by a rapid decrease at $8.2 \mathrm{kyr}$ is observed in the brassicasterol and $\mathrm{IP}_{25}$ flux records. Subsequently, from about 8 to $5 \mathrm{kyr} \mathrm{BP}, \mathrm{IP}_{25}$, brassicasterol and organic carbon fluxes all remained low, similar to the Early Younger Dryas (or IACP) and the LGM when near-permanent sea-ice coverage severely restricted primary production. The ' $8.2 \mathrm{kyr}$ event', a significant cold spell probably caused by the outburst of a giant glacial meltwater lake in North America ${ }^{28}$, probably triggered an abrupt increase in sea-ice coverage at the western Yermak Plateau at the end of the Early Holocene Climate Optimum. Although the GISP2 $\delta^{18} \mathrm{O}$ decline at $8.2 \mathrm{kyr}$ вP describes a relatively short-term atmospheric cooling event in Greenland, the longer-term minimum fluxes of $\mathrm{IP}_{25}$ and brassicasterol in the northern Fram Strait suggest a more prolonged deterioration in the marine conditions, 
with near-perennial sea-ice cover. This is reversed in the Late Holocene (since about $5 \mathrm{kyr}$ вр), with slightly increasing organic carbon and brassicasterol fluxes indicative of an amelioration of the environmental conditions at the Yermak Plateau. Concurrent higher fluxes of $\mathrm{IP}_{25}$ point to the re-establishment of seasonal sea-ice conditions in the northern Fram Strait. These observations are consistent with the widespread evidence for a neoglacial period in the northern North Atlantic during the Holocene ${ }^{20,27}$.

This is the first application of the novel sea-ice biomarker $\operatorname{IP}_{25}$ in determining Arctic sea-ice records before the Holocene. We also show how the variable occurrence of $\mathrm{IP}_{25}$, when considered alongside other geochemical proxies such as brassicasterol from phytoplankton, can reveal more specific palaeo-sea-ice scenarios. The co-occurrence of the two biomarkers refers to either seasonal sea-ice cover (Early and Late Holocene) or a stationary ice margin (Late Weichselian) allowing spring sea-ice diatom and summer phytoplankton growth, with the latter scenario indicated further by the additional enhancement of sedimentary ice-rafted detritus ${ }^{11}$. In contrast, near-zero occurrences of both biomarkers (LGM and Early Younger Dryas/IACP) result from unfavourable environmental conditions for both organism classes during extreme cold periods with near-perennial sea-ice cover. Furthermore, the predominant occurrence of $\mathrm{IP}_{25}$ (early deglaciation) or brassicasterol (Early Bølling) indicates the progressive thinning of the sea-ice cover, or sea-ice-free conditions, respectively. As such, the relationship between $\mathrm{IP}_{25}$ and brassicasterol fluxes is strongly dependent on the specific sea-ice conditions, shown further by the variable correlation between these two biomarkers at different intervals across the record (Fig. 2).

As shown, our biomarker-based observations and interpretations align strongly with previous palaeoclimate records for the northern Fram Strait ${ }^{9,12,19,23}$, but they also provide more specific palaeoceanographic information. First, during intervals of the Late Weichselian, our biomarker record indicates extended periods of near-perennial sea-ice cover (29-27.5 kyr вP and 23.5-17 kyr вP; Fig. 2), yet high fluxes of planktic and benthic foraminifera have been identified previously in PS2837-5, and these were attributed to a stronger though, significantly, subsurface input of warm Atlantic water $^{11,23}$ during so-called high-productive events ${ }^{29}$. We suggest that a temperate subsurface layer, causing thinning and short-term opening of the ice sheet during summer months (Fig. 3a), was sufficient for short-term blooms of phytoplankton-grazing foraminifera without significant deposition of marine surface-water or sea-icederived biomarkers (23.5-17 kyr вр). Second, significantly higher biomarker fluxes are observed during an interval (27-24 kyr вр) barren of planktic foraminifers ${ }^{11}$, which may be ascribed to enhanced sedimentary carbonate dissolution ${ }^{11,19,23,30}$ as a consequence of elevated sea-surface primary productivity at the ice edge during polynya conditions. These observations further reinforce the importance of evaluating the significance of individual proxies when carrying out integrated palaeoclimate reconstructions.

\section{Methods}

The analysis of the $\mathrm{IP}_{25}$ biomarker was carried out on freeze-dried sediment material from individual horizons from the PS2837-5 core. Before extraction, an internal standard (7-hexylnonadecane) was added to about $1.5 \mathrm{~g}$ freeze-dried and ground sediment material to permit quantification. Sediments were then extracted using dichloromethane/methanol $(3 \times 3 \mathrm{ml} ; 2: 1 \mathrm{vol} / \mathrm{vol})$ and ultrasonication $(3 \times 10 \mathrm{~min})$. The resulting extracts were fractionated to yield hydrocarbon fractions containing $\mathrm{IP}_{25}$ using open-column chromatography $\left(\mathrm{SiO}_{2}\right.$, hexane), and these were analysed using gas chromatography-mass spectrometry (GC-MS). Gas chromatography-mass spectrometry measurements were carried out on a HP 5,890 gas chromatograph ( $30 \mathrm{~m}$ fused silica column; $0.25 \mathrm{~mm}$ inner diameter, $0.25 \mu \mathrm{m}$ film thickness) coupled to an HP 5970 mass-selective detector. The GC oven temperature was programmed from 40 to $300^{\circ} \mathrm{C}$ at $5^{\circ} \mathrm{C} \mathrm{min}^{-1}$ and held at the final temperature for $10 \mathrm{~min}$. Mass spectrometry operating conditions were $280^{\circ} \mathrm{C}$ (ion source) and $70 \mathrm{eV}$ (ionization energy). Deviation for the repeatability of measurements was less than $10 \%$. The identification of the $\mathrm{IP}_{25}$ monoene was based on its GC retention time and comparison of its mass spectrum with that of an authentic standard published previously ${ }^{6}$. Sedimentary $\mathrm{IP}_{25}$ concentrations were determined by calculating the relative gas chromatography-mass spectrometry responses of $\mathrm{IP}_{25}$ and the internal standard and taking account of the mass of sediment extracted in each case. Temporal fluxes of $\mathrm{IP}_{25}$ and brassicasterol were determined by combining sedimentary concentrations with sediment densities and sedimentation rates.

Received 4 May 2009; accepted 24 September 2009; published online 25 October 2009

\section{References}

1. Rudels, B. in The Arctic and Environmental Change (eds Wadhams, P., Dowdeswell, J. A. \& Schofield, A. N.) 87-99 (Gordon and Breach, 1996).

2. Dieckmann, G. S. \& Hellmer, H. H. in Sea Ice (eds Thomas, D. N. \& Dieckmann, G. S.) 1-21 (Blackwell, 2003).

3. Severinghaus, J. P. \& Brook, E. J. Abrupt climate change at the end of the last glacial period inferred from trapped air in polar ice. Science 286, 930-934 (1999).

4. Koc, N., Jansen, E. \& Haflidason, H. Paleoceanographic reconstructions of surface ocean conditions in the Greenland, Iceland and Norwegian seas through the last $14 \mathrm{kyr}$ based on diatoms. Quat. Sci. Rev. 12, 115-140 (1993)

5. Andersen, C., Koc, N., Jennings, A. \& Andrews, J. T. Nonuniform response of the major surface currents in the Nordic Seas to insolation forcing: Implications for the Holocene climate variability. Paleoceanography 19, PA2003 (2004).

6. Belt, S. T. et al. A novel chemical fossil of palaeo sea ice: $\mathrm{IP}_{25}$. Org. Geochem. 38, 16-27 (2007).

7. Massé, G. et al. Abrupt climate changes for Iceland during the last millennium: Evidence from high resolution sea ice reconstructions. Earth Planet. Sci. Lett. 269, 565-569 (2008).

8. Volkman, J. K. et al. Microalgal biomarkers: A review of recent research developments. Org. Geochem. 29, 1163-1179 (1998).

9. Birgel, D. \& Hass, H. C. Oceanic and atmospheric variations during the last deglaciation in the Fram Strait (Arctic Ocean): A coupled high-resolution organic-geochemical and sedimentological study. Quat. Sci. Rev. 23, 29-47 (2004).

10. Stein, R. \& Fahl, K. Scientific cruise report of the arctic expedition ARK-XIII/2 of RV Polarstern in 1997. Ber. Polarforsch. 255, 98-136 (1997).

11. Nørgaard-Pedersen, N. et al. Arctic Ocean during the Last Glacial Maximum: Atlantic and polar domains of surface water mass distribution and ice cover. Paleoceanography 18, 1063-1082 (2003).

12. Andersen, E. S., Dokken, T. M., Elverhøi, A., Solheim, A. \& Fossen, I. Late quaternary sedimentation and glacial history of the western Svalbard continental margin. Mar. Geol. 133, 123-156 (1996).

13. Mangerud, J. et al. Fluctuations of the Svalbard-Barents sea ice sheet during the last 150,000 years. Quat. Sci. Rev. 17, 11-42 (1998).

14. Sarnthein, M., Pflaumann, U. \& Weinelt, M. Past extent of sea ice in the northern North Atlantic inferred from foraminiferal paleotemperature estimates. Paleoceanography 18, 1047-1058 (2003).

15. Birgel, D. \& Stein, R. in The Organic Carbon Cycle in the Arctic Ocean (eds Stein, R. \& MacDonald, G. M.) (Springer, 2004).

16. Knies, J. \& Stein, R. New aspects of organic carbon deposition and its paleoceanographic implications along the northern Barents Sea margin during the last 30,000 years. Paleoceanography 13, 384-394 (1998).

17. Smith, W. O. Jr, Baumann, M. E. M., Wilson, D. L. \& Aletsee, L. Phytoplankton biomass and productivity in the marginal ice zone of the Fram Strait during summer 1984. J. Geophys. Res. 92, 6777-6786 (1987).

18. Birgel, D., Stein, R. \& Hefter, J. Aliphatic lipids in recent sediments of the Fram Strait/Yermak Plateau (Arctic Ocean): composition, sources and transport processes. Mar. Chem. 88, 127-160 (2004).

19. Knies, J., Vogt, C. \& Stein, R. Late Quaternary growth and decay of the Svalbard/Barents Sea ice sheet and paleoceanographic evolution in the adjacent Arctic Ocean. Geo-Mar. Lett. 18, 195-202 (1999).

20. Stein, R. Arctic Ocean Sediments: Processes, Proxies, and Paleoenvironment (Elsevier, 2008).

21. Knies, J., Kleiber, H.-P., Matthiessen, J., Müller, C. \& Nowaczyk, N. Marine ice-rafted debris records constrain maximum extent of Saalian and Weichselian ice-sheets along the northern Eurasian margin. Glob. Planet. Change 31, 45-64 (2001).

22. Grootes, P. M., Stuiver, M., White, J. W. C., Johnsen, S. \& Jouzel, J. Comparison of oxygen isotope records from the GISP2 and GRIP Greenland ice cores. Nature 366, 552-554 (1993).

23. Wollenburg, J. E., Knies, J. \& Mackensen, A. High-resolution paleoproductivity fluctuations during the past $24 \mathrm{kyr}$ as indicated by benthic foraminifera in the marginal Arctic Ocean. Palaeogeogr. Palaeoclimatol. Palaeoecol. 204, 209-238 (2004)

24. Bondevik, S., Mangerud, J., Birks, H. H., Gulliksen, S. \& Reimer, P. Changes in north Atlantic radiocarbon reservoir ages during the Allerød and Younger Dryas. Science 312, 1514-1517 (2006). 
25. Bradley, R. S. \& England, J. H. The Younger Dryas and the sea of ancient ice. Quat. Res. 70, 1-10 (2008).

26. Slubowska-Woldengen, M. et al. Time-slice reconstructions of ocean circulation changes on the continental shelf in the Nordic and Barents Seas during the last 16,000 cal yr вр. Quat. Sci. Rev. 27, 1476-1492 (2008).

27. Hald, M. et al. Variations in temperature and extent of Atlantic Water in the northern North Atlantic during the Holocene. Quat. Sci. Rev. 26, 3423-3440 (2007).

28. Kleiven, H. F. et al. Reduced north Atlantic deep water coeval with the Glacial Lake Agassiz freshwater outburst. Science 319, 60-64 (2008).

29. Hebbeln, D., Dokken, T., Andersen, E. S., Hald, M. \& Elverhøi, A. Moisture supply for northern ice-sheet growth during the Last Glacial Maximum. Nature 370, 357-360 (1994).

30. Steinsund, P. I. \& Hald, M. Recent calcium carbonate dissolution in the Barents Sea: Paleoceanographic applications. Mar. Geol. 117, 303-316 (1994).

\section{Acknowledgements}

We thank S. J. Rowland and D. Birgel for discussions on the use of selected biomarkers and for provision of some geochemical data from PS2837-5. Financial support was provided by the Deutsche Forschungsgemeinschaft, STE 412/24-1, the European Research Council (StG project 203441) and the UK Natural Environmental Research Council (NE/D013216/1).

\section{Author contributions}

All authors contributed equally to this work; S.T.B. and G.M. designed the analytical method; J.M. carried out experiments, analysed data and drafted the original manuscript; all authors interpreted the results and contributed to the final manuscript.

\section{Additional information}

Reprints and permissions information is available online at http://npg.nature.com/ reprintsandpermissions. Correspondence and requests for materials should be addressed to J.M. 